Journal of Finance and Investment Analysis, Vol. 9, No. 4, 2020, 1-16

ISSN: 2241-0998 (print version), 2241-0996 (online)

https://doi.org/10.47260/jfia/941

Scientific Press International Limited

\title{
Effects of Asset Allocation on Financial Performance of Unit Trust Schemes in Kenya
}

\author{
Humphrey Mokaya ${ }^{1}$, Ronald Chogi ${ }^{2}$ and Winnie Nyamute ${ }^{3}$
}

\begin{abstract}
Unit Trust Schemes provide diversification, liquidity, professional management among other benefits. In order to diversify the funds raised from various unit holders, fund managers adopt a criterion with which funds are allocated optimally. A descriptive research design was adopted, and the study period was 5-years. The ratio of the composition of different asset classes to the fund value was used as the independent variables. Fund age was used as the control variable. Sharpe ratio was used to measure investment returns and that represented the dependent variable of the study. Data was collected from secondary sources and a multiple linear regression model was adopted to assess the association of the variables. Collected data showed normality traits, positive autocorrelation when measured using Pearson correlation coefficients. The data also showed mixed results for multicollinearity tests. The weight of money market instruments, corporate bonds, treasury bonds and equity significantly affected performance of Unit Trust Scheme funds. They all had probability values in the interval of 0 and 0.05 . Therefore, the study concluded that asset allocation significantly affects how a fund will perform. Other factors such as timing, manager experience and prevailing economic conditions have to be considered when evaluating performance of a fund.
\end{abstract}

Keywords: Asset allocation, Financial performance, Unit trust schemes, Kenya.

\footnotetext{
1 Business Analyst, Finance Department, KOKO Networks Limited.

${ }^{2}$ Lecturer, Department of Finance and Accounting, School of Business, University of Nairobi.

3 Senior Lecturer, Department of Finance and Accounting, School of Business,

University of Nairobi.
}

Article Info: Received: September 9, 2020. Revised: October 4, 2020.

Published online: November 5, 2020. 


\section{Introduction}

Deciding on an appropriate mix of financial assets which an investor's funds will be allocated is a decision fund manager have to make throughout their daily investing operations. Investment is not a matter of picking stocks and other asset classes to put your money in, but it is about choosing the right combination of financial asset classes where one can put their money in (Karimi, 2013). Therefore, asset allocation is an important decision which differentiates between a poorly performing scheme and one which offers attractive returns to the investors. Investment returns point to how a scheme is financially performing. Asset allocation is also regarded as an investment strategy (Dziwok, 2014). An appropriate strategy allows the fund manager to profile investors in terms of the risk levels they can tolerate, their investment preferences and how they rate the fund (Velusamy and Selvaveerakumar, 2014).

Various models have been developed in a bid to explain the inter-relationship which exists between investment returns and the risk involved. Risk underlies asset allocation. (Sharpe, 1964) and (Lintner, 1965) developed CAPM to describe expected returns of a security and the risk involved. (Markowitz, 1952) developed the modern portfolio theory (MPT) to serve as a guide towards building optimal portfolios given the assumption that investors are risk averse. MPT guide ensures delivery of maximum returns on the lowest risk levels. Later, (Sharpe, 1966) developed a ratio to explain the return of an investment compared to its risk which came to be popularly known as Sharpe's ratio.

Unit Trust Schemes primarily invest in equity, money market instruments and fixed interest financial instruments. Trends have emerged where Unit Trusts are diversifying their investments by not only investing in local instruments but making investments in foreign financial instruments as well. In Kenya, Unit trust schemes growth has been steady having grown from almost zero schemes in 2001 up to 11 in the year 2008 and 18 in 2018. This is according to a CMA study on the low uptake of capital market products published in June 2018. Assets under management in Kenya has also been growing standing at Ksh 61.5 Billion in 2019 notes a quarter 1 report by CMA. This is attributed to better asset allocation practices which ultimately lead to better investment returns.

\section{Preliminary Notes}

\subsection{Definition}

Simple linear regression was used to analyze data in order to establish the stretch to which asset allocation affects financial performance of a Unit Trust Scheme. Further, descriptive statistics were used to represent the general information of the data collected. SPSS and Excel were used in analysis and presentation of data.

The below research model was adopted: -

$S_{f p}=\alpha+\beta_{1} x_{1}+\beta_{2} x_{2+} \beta_{3} x_{3}+\beta_{4} x_{4}+\beta_{5} x_{5+} \beta_{6} x_{6+} \varepsilon$ 
Whereby $S_{\mathrm{fp}}$ refers to fund performance of Unit Trust Schemes measured using Sharpe's ratio whose formula is shown below:

Sharpe ratio, $S_{f p}=\frac{R_{p}-R_{f}}{\sigma_{p}}$

Where $R_{p}$ is the expected portfolio return, $R_{f}$ is the risk-free rate which was obtained from the yield of a 10-year Treasury bond and $\sigma_{p}$ is the standard deviation of the portfolio's excess return.

$\alpha$ - refers to a constant of the model which is the risk-free rate of return obtained from the yield of a 10-year Treasury bond.

$x_{1}$ - the weight of investment in treasury bonds by the scheme. This is calculated as a proportion of the value of investment in treasury bonds by the scheme divided by the total scheme value.

$x_{2}$-the weight of investment in corporate bonds by the scheme. This is calculated as a proportion of the value of investment in corporate bonds by the scheme divided by the total scheme value.

$x_{3}-$ the weight of investment in equities by the scheme. This is calculated as a proportion of the value of investment in equities by the scheme divided by the total scheme value.

$x_{4}-$ the weight of property investment by the scheme. This is calculated as a proportion of the value of investment in properties by the scheme divided by the total scheme value.

$x_{5}-$ the weight investment in money market instruments by the scheme. This is calculated as a proportion of the value investment in money market instruments by the scheme divided by the total scheme value.

$\mathrm{x}_{6}$ - Fund age.

$\beta_{1,} \beta_{2,} \beta_{3}, \beta_{4}, \beta_{5}$ and $\beta_{6}$ refer to parameters to be estimated for the determinants of financial performance.

$\varepsilon$ is the error term.

\section{Main Results}

\subsection{Introduction}

Secondary data was collected by the researcher using data collection forms. The data was entered into Excel and coded as appropriate. The Excel file was imported into SPSS where analysis took place. Descriptive and inferential analysis was done. The results are as presented in the subsequent sections.

\subsection{Response Rate}

The researcher targeted 75 active Unit Trust Schemes in Kenya as of $31^{\text {st }}$ December 2018. Data was collected over a 5-year period, 2014 to 2018. Therefore, N was equivalent to $375,75^{*} 5$. However, the researcher was able to collect data for 50 
funds over a 5-year period and one fund over a 2-year period. This gives a response rate of 252. This represents a response rate of $67 \%$ and a non-response rate of $33 \%$ as represented in the pie chart below.

\section{Response Rate}

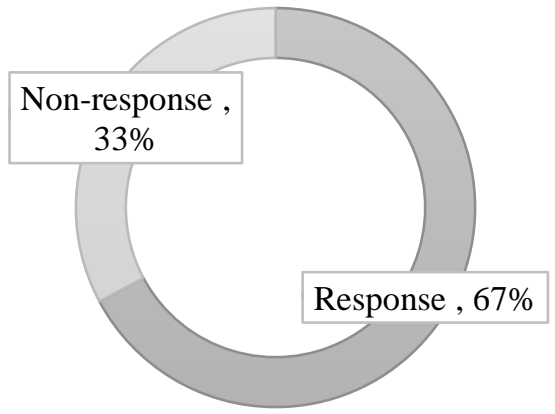

Figure 1: Response rates

Fincham (2008) in his research on response rates and responsiveness for surveys, standards and the journal note that response rates of approximately $60 \%$ should be the goal of most researchers and certainly the expectation of most editors of journals. With a response rate of $67 \%$, the researcher was satisfied that it was representative of the population under study.

\subsection{Descriptive Statistics}

Mean, standard deviation, skewness and kurtosis were used to bring out the descriptive elements of the data under study. The results are as presented in the table below: 
Table 1: Descriptive statistics

\begin{tabular}{|l|c|c|c|c|c|c|c|}
\hline & N & Mean & $\begin{array}{c}\text { Std. } \\
\text { Deviation }\end{array}$ & \multicolumn{2}{|c|}{ Skewness } & \multicolumn{2}{|c|}{ Kurtosis } \\
\cline { 2 - 8 } & Statistic & Statistic & Statistic & Statistic & $\begin{array}{c}\text { Std. } \\
\text { Error }\end{array}$ & Statistic & $\begin{array}{c}\text { Std. } \\
\text { Error }\end{array}$ \\
\hline $\begin{array}{l}\text { Money } \\
\text { Market }\end{array}$ & 252 & 0.19 & 0.15 & 0.68 & 0.15 & -0.48 & 0.31 \\
\hline $\begin{array}{l}\text { Corporate } \\
\text { Bonds }\end{array}$ & 252 & 0.12 & 0.14 & 0.67 & 0.15 & -1 & 0.31 \\
\hline Property & 252 & 0 & 0.03 & 7.86 & 0.15 & 64.52 & 0.31 \\
\hline $\begin{array}{l}\text { Treasury } \\
\text { Bonds }\end{array}$ & 252 & 0.43 & 0.16 & -0.57 & 0.15 & 1.18 & 0.31 \\
\hline Equity & 252 & 0.25 & 0.22 & 0.26 & 0.15 & -1.16 & 0.31 \\
\hline Fund Age & 252 & 0.68 & 0.37 & -1.12 & 0.15 & 0.91 & 0.31 \\
\hline $\begin{array}{l}\text { Fund } \\
\text { Returns }\end{array}$ & 252 & -0.15 & 1 & -0.3 & 0.15 & 0.22 & 0.31 \\
\hline
\end{tabular}

From table 1 above, the weight of the money market instruments had a mean of 0.19 , a standard deviation of 0.15 , skewness of 0.68 and a kurtosis of -0.48 . The weight of corporate bonds had a mean of 0.12 , a standard deviation of 0.14 , skewness of 0.67 and a kurtosis of -1.00 . The weight of immovable property had a standard deviation of 0.03 , skewness of 7.86 and a kurtosis of 64.52 . The weight of treasury bonds had a mean of 0.43 , a standard deviation of 0.16 , skewness of -0.57 and a kurtosis of 1.18. The weight of equity had a mean of 0.25 , a standard deviation of 0.22 , skewness of 0.26 and a kurtosis of -1.16 . The age of the fund expressed as a logarithm of the fund age had a mean of 0.68 , a standard deviation of 0.37 , skewness of -1.12 and a kurtosis of 0.91 . Fund returns which was expressed as a Sharpe ratio had a mean of -0.15 , a standard deviation of 1.00 , skewness of -0.30 and a kurtosis of 0.22 .

The results of the analysis show that the age of the fund had the largest mean and the fund returns had the smallest mean. Fund returns had the largest standard deviation and the weight of property had the least standard deviation. Property had the largest skewness whereas fund age showed the least. Property had the largest kurtosis and the weight of equity had the least.

\subsection{Diagnostic Tests}

Diagnostic tests for normality, multi-collinearity and autocorrelation were run on the data and the results are as presented below: 


\subsubsection{Normality Test}

Plotting a normal probability histogram of the standardized regression residuals was run as shown in the diagram below. This showed that the normality assumption is satisfied in the above regression equation.

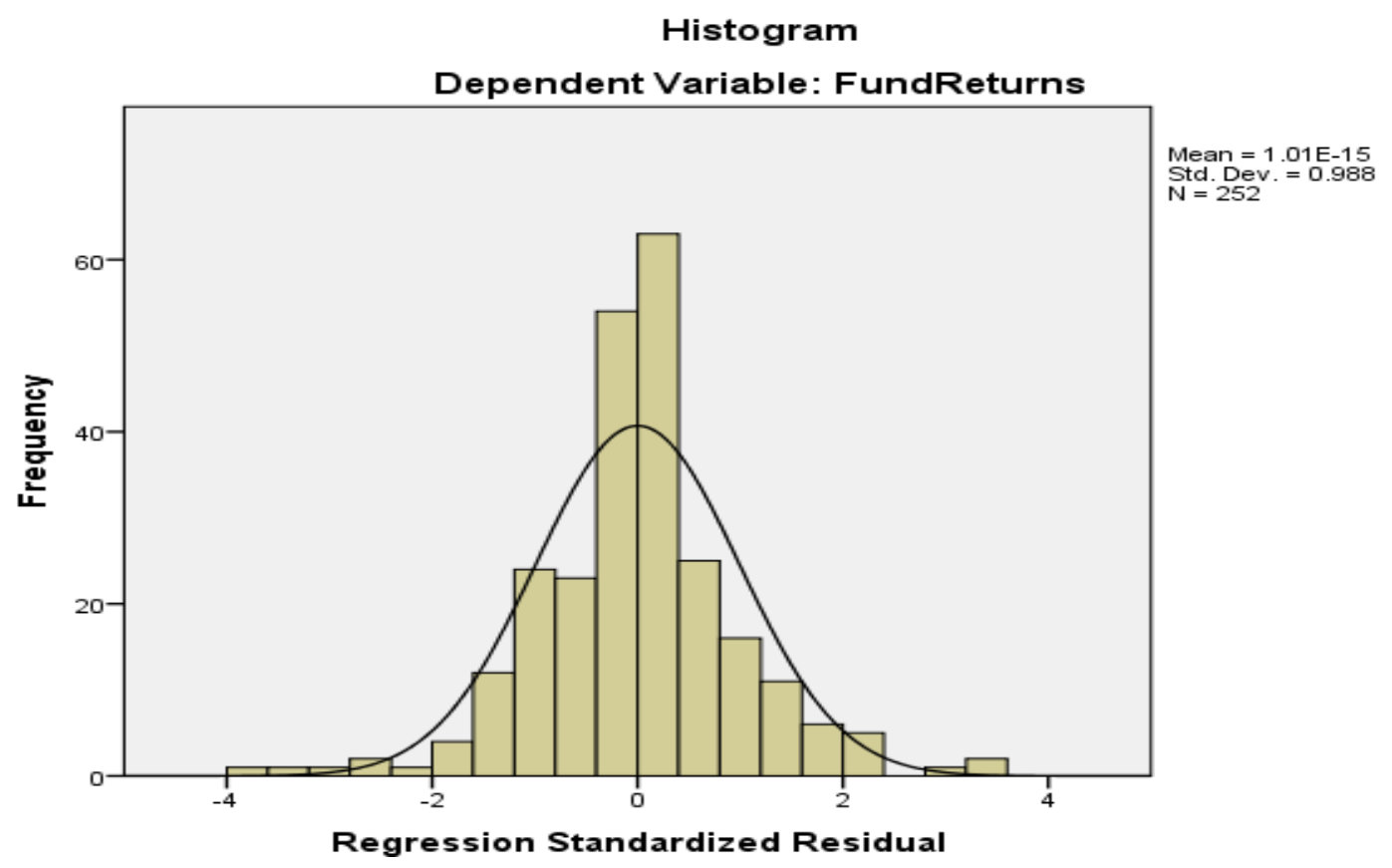

Figure 2: Standardized Residuals Histogram

\subsubsection{Autocorrelation}

Table 2: Autocorrelation Table

\begin{tabular}{|c|c|c|c|c|}
\hline Model & R & R Square & $\begin{array}{c}\text { Adjusted } \\
\text { R Square }\end{array}$ & $\begin{array}{c}\text { Std. Error of the } \\
\text { Estimate }\end{array}$ \\
\hline 1 & $.692^{\mathrm{a}}$ & .479 & .466 & .73078 \\
\hline
\end{tabular}

a. Predictors: (Constant), Fund Age, Corporate Bonds, Property, Treasury Bonds, Money Market, Equity

Table 2 showed that the model had a correlation coefficient, $\mathrm{R}$ of 0.692 . This signifies existence of a strong positive association between the variables of the study. The model also had a coefficient of determination, R Square of 0.479 . This was interpreted to imply that $47.9 \%$ of the fund returns for Unit Trust Scheme funds in Kenya can be explained by the independent variables of this study. 


\subsubsection{Multicollinearity Test}

Collinearity diagnostic tests were run on the data to test for multi-collinearity. Tolerance probability was obtained, and the Variance Inflation factors (VIF) were used to evaluate existence and non-existence of multicollinearity among the independent variables.

When VIF ranges from 0 to 2.99 , it shows non-existence of multi collinearity among the independent variables. A VIF value of 3 to 4.99 shows that we probably have multi collinearity. A value of 5 to 9.99 shows that we most likely have multi collinearity among the independent variables. A VIF value of 10 or more shows that we definitely do have multi-collinearity among the independent variables.

Iterative diagnostic tests were run on the data and the results are as summarized in the table below: 
Table 3: Collinearity Diagnostics

\begin{tabular}{|c|c|c|c|c|c|c|c|}
\hline \multicolumn{4}{|c|}{ Coefficients $^{\mathbf{a}}$} & \multicolumn{4}{|c|}{ Coefficients $^{\mathbf{a}}$} \\
\hline & \multirow{2}{*}{ Model } & \multicolumn{2}{|c|}{ Collinearity Statistics } & \multirow{2}{*}{\multicolumn{2}{|c|}{ Model }} & \multicolumn{2}{|c|}{ Collinearity Statistics } \\
\hline & & Tolerance & VIF & & & Tolerance & VIF \\
\hline \multirow{5}{*}{1} & $\begin{array}{c}\text { Corporate } \\
\text { Bonds }\end{array}$ & 0.512 & 1.952 & \multirow{5}{*}{1} & Property & 0.934 & 1.071 \\
\hline & Property & 0.966 & 1.035 & & $\begin{array}{c}\text { Treasury } \\
\text { Bonds }\end{array}$ & 0.483 & 2.072 \\
\hline & Treasury Bonds & 0.509 & 1.965 & & Equity & 0.384 & 2.602 \\
\hline & Equity & 0.392 & 2.551 & & Fund Age & 0.93 & 1.075 \\
\hline & Fund Age & 0.927 & 1.078 & & Money Market & 0.468 & 2.138 \\
\hline \multicolumn{4}{|c|}{ a. Dependent Variable: Money Market } & \multicolumn{4}{|c|}{ a. Dependent Variable: Corporate Bonds } \\
\hline \multicolumn{4}{|c|}{ Coefficients $^{\mathrm{a}}$} & \multicolumn{4}{|c|}{ Coefficients $^{\mathrm{a}}$} \\
\hline \multirow{2}{*}{\multicolumn{2}{|c|}{ Model }} & \multicolumn{2}{|c|}{ Collinearity Statistics } & \multirow{2}{*}{\multicolumn{2}{|c|}{ Model }} & \multicolumn{2}{|c|}{ Collinearity Statistics } \\
\hline & & Tolerance & VIF & & & Tolerance & VIF \\
\hline \multirow{5}{*}{1} & Equity & 0.528 & 1.893 & \multirow{5}{*}{1} & Fund Age & 0.931 & 1.074 \\
\hline & Fund Age & 0.929 & 1.077 & & Money Market & 0.889 & 1.125 \\
\hline & Money Market & 0.681 & 1.468 & & $\begin{array}{c}\text { Corporate } \\
\text { Bonds }\end{array}$ & 0.955 & 1.047 \\
\hline & $\begin{array}{l}\text { Corporate } \\
\text { Bonds }\end{array}$ & 0.707 & 1.414 & & Property & 0.977 & 1.023 \\
\hline & Property & 0.94 & 1.063 & & $\begin{array}{l}\text { Treasury } \\
\text { Bonds }\end{array}$ & 0.895 & 1.117 \\
\hline \multicolumn{4}{|c|}{ a. Dependent Variable: Treasury Bonds } & \multicolumn{4}{|c|}{ a. Dependent Variable: Equity } \\
\hline \multicolumn{4}{|c|}{ Coefficients $^{\mathrm{a}}$} & \multicolumn{4}{|c|}{ Coefficients $^{\mathbf{a}}$} \\
\hline \multirow{2}{*}{\multicolumn{2}{|c|}{ Model }} & \multicolumn{2}{|c|}{ Collinearity Statistics } & \multirow{2}{*}{\multicolumn{2}{|c|}{ Model }} & \multicolumn{2}{|c|}{ Collinearity Statistics } \\
\hline & & Tolerance & VIF & & & Tolerance & VIF \\
\hline \multirow{5}{*}{1} & Treasury Bonds & 0.063 & 15.949 & \multirow{5}{*}{1} & Money Market & 0.037 & 27.126 \\
\hline & Equity & 0.038 & 26.025 & & $\begin{array}{c}\text { Corporate } \\
\text { Bonds }\end{array}$ & 0.041 & 24.683 \\
\hline & Fund Age & 0.938 & 1.066 & & Property & 0.418 & 2.392 \\
\hline & Money Market & 0.086 & 11.599 & & $\begin{array}{l}\text { Treasury } \\
\text { Bonds }\end{array}$ & 0.028 & 36.24 \\
\hline & $\begin{array}{c}\text { Corporate } \\
\text { Bonds }\end{array}$ & 0.091 & 10.96 & & Equity & 0.016 & 61.273 \\
\hline & a. Dependent V & iable: Prop & & & a. Dependent & iable: Func & Age \\
\hline
\end{tabular}


From the collinearity diagnostic tables above, it was showed that the weight of money market, corporate bonds, treasury bonds and the weight of equity showed no signs of multi-collinearity with the other independent variables since all their VIF values are less than 3 .

However, the weight of property showed existence of multi-collinearity with all the independent variables except fund age. Fund age also showed existence of multicollinearity with all the independent variables except the weight of property.

\subsection{Correlation Analysis}

Pearson correlations were also run to determine the direction and strength of the relationship between the study variables. The results are presented in the table below:

Table 4: Correlations

\begin{tabular}{|c|c|c|c|c|c|c|c|c|}
\hline & & $\begin{array}{l}\text { Money } \\
\text { Market }\end{array}$ & $\begin{array}{c}\text { Corporate } \\
\text { Bonds }\end{array}$ & Property & $\begin{array}{c}\text { Treasury } \\
\text { Bonds }\end{array}$ & Equity & $\begin{array}{c}\text { Fund } \\
\text { Age }\end{array}$ & $\begin{array}{c}\text { Fund } \\
\text { Returns }\end{array}$ \\
\hline \multirow[t]{3}{*}{$\begin{array}{l}\text { Money } \\
\text { Market }\end{array}$} & $\begin{array}{c}\text { Pearson } \\
\text { Correlation }\end{array}$ & 1 & .016 & -.120 & -.220 & -.478 & -.213 & .344 \\
\hline & Sig. (2-tailed) & & .802 & .058 & .000 & .000 & .001 & .000 \\
\hline & $\mathrm{N}$ & 252 & 252 & 252 & 252 & 252 & 252 & 252 \\
\hline \multirow[t]{3}{*}{$\begin{array}{l}\text { Corporate } \\
\text { Bonds }\end{array}$} & $\begin{array}{c}\text { Pearson } \\
\text { Correlation }\end{array}$ & .016 & 1 & -.025 & -.206 & -.471 & -.006 & .436 \\
\hline & Sig. (2-tailed) & .802 & & .695 & .001 & .000 & .923 & .000 \\
\hline & $\mathrm{N}$ & 252 & 252 & 252 & 252 & 252 & 252 & 252 \\
\hline \multirow[t]{3}{*}{ Property } & $\begin{array}{c}\text { Pearson } \\
\text { Correlation }\end{array}$ & -.120 & -.025 & 1 & .013 & -.066 & .113 & .045 \\
\hline & Sig. (2-tailed) & .058 & .695 & & .839 & .295 & .073 & .473 \\
\hline & $\mathrm{N}$ & 252 & 252 & 252 & 252 & 252 & 252 & 252 \\
\hline \multirow[t]{3}{*}{$\begin{array}{l}\text { Treasury } \\
\text { Bonds }\end{array}$} & $\begin{array}{c}\text { Pearson } \\
\text { Correlation } \\
\end{array}$ & -.220 & -.206 & .013 & 1 & -.488 & -.073 & .215 \\
\hline & Sig. (2-tailed) & .000 & .001 & .839 & & .000 & .250 & .001 \\
\hline & $\mathrm{N}$ & 252 & 252 & 252 & 252 & 252 & 252 & 252 \\
\hline \multirow[t]{3}{*}{ Equity } & $\begin{array}{c}\text { Pearson } \\
\text { Correlation }\end{array}$ & -.478 & -.471 & -.066 & -.488 & 1 & .190 & -.654 \\
\hline & Sig. (2-tailed) & .000 & .000 & .295 & .000 & & .003 & .000 \\
\hline & $\mathrm{N}$ & 252 & 252 & 252 & 252 & 252 & 252 & 252 \\
\hline \multirow[t]{3}{*}{ Fund Age } & $\begin{array}{c}\text { Pearson } \\
\text { Correlation }\end{array}$ & -.213 & -.006 & .113 & -.073 & .190 & 1 & -.119 \\
\hline & Sig. (2-tailed) & .001 & .923 & .073 & .250 & .003 & & .059 \\
\hline & $\mathrm{N}$ & 252 & 252 & 252 & 252 & 252 & 252 & 252 \\
\hline \multirow[t]{3}{*}{$\begin{array}{l}\text { Fund } \\
\text { Returns }\end{array}$} & $\begin{array}{c}\text { Pearson } \\
\text { Correlation } \\
\end{array}$ & .344 & .436 & .045 & .215 & -.654 & -.119 & 1 \\
\hline & Sig. (2-tailed) & .000 & .000 & .473 & .001 & .000 & .059 & \\
\hline & $\mathrm{N}$ & 252 & 252 & 252 & 252 & 252 & 252 & 252 \\
\hline
\end{tabular}


Pearson correlation range from -1 to +1 . A coefficient of 0.1 to 0.29 or -0.1 and 0.29 indicate weak strength of association between the variables. A correlation of 0.3 to 0.49 or -0.3 and -0.49 point to a medium strength of association between the study variables. A coefficient of 0.5 to 1 or -0.5 and -1 indicate a strong or large strength of association.

Table 4 above showed Pearson correlation coefficients and 2-tailed significance probability levels. The Pearson correlation for the weight of money market instruments was 0.344 with a probability value of less than 0.05 . This showed existence of moderate positive association between the weight of money market instruments and the fund returns which is significant at $5 \%$ level of confidence. The weight of corporate bonds had a Pearson correlation coefficient of 0.436 with a 2tailed probability of less than $5 \%$. This pointed to the existence of a moderate positive relationship between the weight of corporate bonds in a fund to the fund returns. The probability is also significant at 5\% confidence interval.

The weight of property had a Pearson correlation coefficient of 0.045 with a 2-tailed significance probability of 0.473 . This showed that there existed weak positive relationship between the weight of property and the performance of a fund which was measured by its investment returns. The probability is not significant at a confidence interval of 5\%. The weight of treasury bonds in the fund had a Pearson correlation coefficient of 0.215 with a significance probability of 0.001 . This pointed to existence of a weak association between the weight of treasury bonds and the fund returns. The positive association means that increasing the weight of treasury bonds in a fund increases the performance of Unit Trust Scheme fund.

The weight of equity had a Pearson correlation coefficient of -0.654 with a significance probability which was less than $5 \%$. This showed existence of a strong negative relationship between the weight of equity in a fund and the returns of a fund. The negative relationship shows that increasing the weight of equity in a fund decreases its one-year performance. The association is significant at a 5\% confidence interval. Fund age had a Pearson correlation coefficient of -0.119 with a significance probability of 0.059 . This showed existence of a weak negative relationship between the log of fund age and the returns of a fund. The association is also not significant at $5 \%$ confidence interval but if the limit is stretched, it will be significant at an interval of $6 \%$.

\subsection{Regression Analysis}

Regression analysis was performed on the data collected to determine the effect which asset allocation had on the performance of Unit Trust Scheme funds in Kenya. The results of the regression analysis are as presented below: 
Table 5: Model Summary

\begin{tabular}{|c|c|c|c|c|}
\hline Model & R & R Square & $\begin{array}{c}\text { Adjusted } \\
\text { R Square }\end{array}$ & $\begin{array}{c}\text { Std. Error of the } \\
\text { Estimate }\end{array}$ \\
\hline 1 & $.692^{\mathrm{a}}$ & .479 & .466 & .73078 \\
\hline
\end{tabular}

a. Predictors: (Constant), Fund Age, Corporate Bonds, Property, Treasury Bonds, Money Market, Equity

Table 6: ANOVA ${ }^{\mathrm{a}}$

\begin{tabular}{|l|c|c|c|c|c|c|}
\hline \multicolumn{2}{|c|}{ Model } & $\begin{array}{c}\text { Sum of } \\
\text { Squares }\end{array}$ & Df & $\begin{array}{c}\text { Mean } \\
\text { Square }\end{array}$ & F & Sig. \\
\hline \multirow{2}{*}{1} & Regression & 120.185 & 6 & 20.031 & 37.508 & $.000^{\mathrm{b}}$ \\
\cline { 2 - 7 } & Residual & 130.841 & 245 & .534 & & \\
\hline
\end{tabular}

Tabulated $\mathrm{F}$ value given the degrees of freedom $(6,245)$ at a $5 \%$ level of significance, the value was found to be 2.13. From table 6 above, the F distribution value is 37.508 and it is way higher than the tabulated critical value. This showed that the model was a good predictor of the relationship which existed between asset allocation and financial performance of Unit Trust Scheme funds in Kenya.

Table 7: Regression coefficients

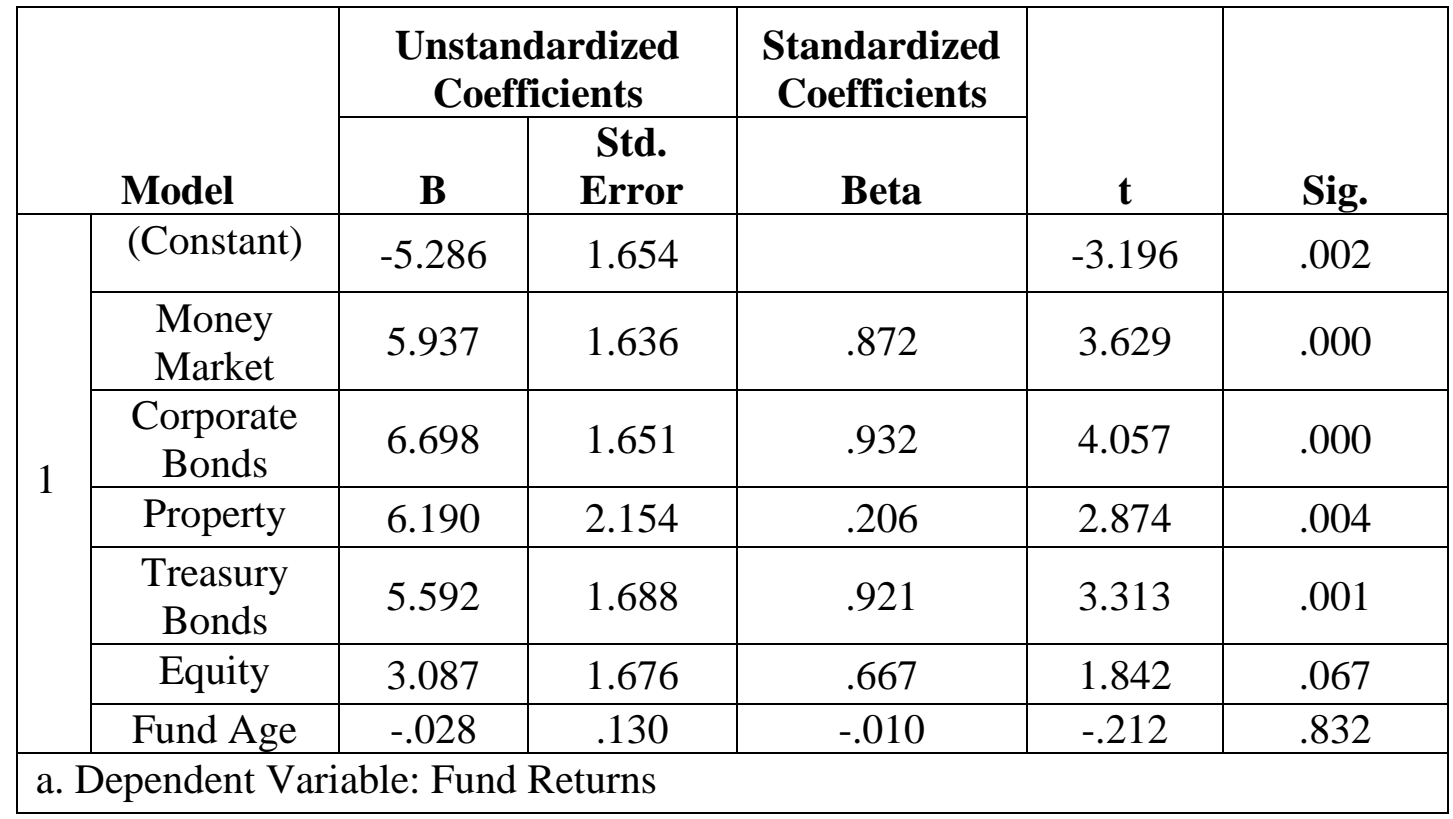


When the coefficients are updated into the analytical model, the resultant regression equation is as below:

$S_{f p}=-5.286+5.592 x_{1}+6.698 x_{2}+3.087 x_{3}+6.190 x_{4}+5.937 x_{5}-0.028 x_{6}$

If all the study variables were to remain constant, performance of Unit Trust Schemes in Kenya will remain at -5.286 . Holding all the variables constant, a unit change in the weight of money market instruments will result in an increase in fund performance by 5.937. A unit change in the weight of corporate bonds when all the other factors are held constant results in an increase of the fund performance by 6.698. When all the other variables are held constant, a unit change in the weight of property results in a 6.190 change in the performance of a fund. A unit change in treasury bonds results in a 5.592 change in the performance of a fund when all the other variables are held constant. A unit change in the weight of equity, results in a 3.087 change in the performance of a fund. When all the variables are held constant, a unit change in the log of fund age results in a -0.028 change in the performance of a fund.

Money market financial instruments, corporate bonds, property, and treasury bonds all have significance probabilities which are less than 0.05 . This showed that they were all significant at the $5 \%$ level of significance. Equity was slightly insignificant with a value of 0.067 which was slightly above the $5 \%$ confidence level. Fund age was insignificant given that it had a probability value of 0.832 and this was way higher than the 0.05 level of significance.

\subsection{Interpretation of Findings and Discussion of the Results}

Diagnostic tests conducted on the data show that the assumptions of the model adopted are satisfied. The assumptions of normality, existence of autocorrelation and non-existence of multi-collinearity between the study variables were satisfied. Results of the correlation and regression analysis of the dataset showed that the weight of money market instruments, corporate bonds, treasury bonds and equity significantly affected performance of Unit Trust Scheme funds. Correlation results for the weight of money market instruments, corporate bonds and treasury bonds showed existence of a positive autocorrelation with the fund returns. This implies that increasing the weight of the financial instruments for the scheme increases financial performance of Unit Trust Schemes. They all had probability values in the interval of 0 and 0.05 . This implied that the association between the dependent and independent variable is statistically significant at $95 \%$ confidence level.

Correlation results for the weight of equity pointed to existence of a negative association between with one-year fund returns. This implied that when the weight of equity is increased in a fund, it tends to lower the fund returns in the short-term. The probability was significant at $95 \%$ level of confidence. The result was also in line with findings by (Sutcliffe, 2004) that equities tend to have a long-term investment horizon for them to bring in attractive returns. 
The log of the age of the fund was not significant given that it had a probability of 0.059 which was slightly above 0.05 . Immovable property had a probability of 0.473 which was also not significant at the $5 \%$ level of significance. This implied that, immovable property had significantly lower influence in the performance of a fund. This is consistent with a study conducted by (Sang, 2017) to assess the effect that asset allocation has on the financial performance of Unit Trust Schemes in Kenya.

The findings of this study that are in line with what (Santacruz, 2011) found that asset allocation accounts for a huge percentage in the variability of the aggregate portfolio returns. The research also concurs with the findings of a study conducted by (Blake, Lehmann and Timmermann, 1998) in the UK that asset allocation is an integral element in the determination of the financial performance of an investment institution. However, correlation and regression results differ on the significance levels of property in influencing performance of a fund. Equity had a negative association with one-year fund performance.

\section{Conclusion}

\subsection{Conclusion and Recommendations}

The study sought to determine what effect asset allocation had on the financial performance of Unit Trust Schemes in Kenya. The study established significant correlations between fund returns and money market instruments, corporate bonds, treasury bonds and equity. Property and fund age had insignificant effects according to the level of confidence adopted. Investment in property had insignificant effects in the short-term on the financial performance of investment organizations. Its assessment over a longer period of time may yield different observations.

On the other hand, equity was found to negatively correlate with one year returns of a fund. Investment in equity requires assessment over medium to long time periods for a proper verdict on its effects to be authoritatively stated. Expanding the confidence interval will see fund age have a correlation with the returns of a fund but its effects were not as significant as the financial instruments do. Immovable property due to its illiquid nature, its effect on the one year returns of a fund was insignificant.

The study further established existence of a significant linear relationship between the investment returns of a fund and money market instruments, corporate bonds, property and treasury bonds. The linearity of the association between the age of a fund and equity was statistically insignificant. Equity is significantly correlated with fund returns but the association is not linear. The correlation between the age of a fund and the returns of a fund was insignificant and their association was not linear. Fund managers in their quest to comply with CMA regulations on the quantities of funds which a certain fund can invest in a particular financial instrument proof to be restrictive. Fund managers end up investing in financial assets which they could otherwise not have invested in. This decreases the investment returns which a fund generates. Relaxing such restrictive regulation while still maintaining a balance 
between risk and return of the investors will enhance innovative investment by fund managers. Asset allocation decision should be left to fund managers to make based on their return-risk assessment of a certain financial instrument but under strict guidelines from CMA. Investment returns largely depend on a fund manager's assessment, selection and timing of an investment and that is not fully put into practice with a quantitative regulation in a certain investment.

Findings of the research point to positive correlations between the returns of a fund and money market instrument, corporate bonds, and treasury bonds. Therefore, this study recommends that for funds where investors expect returns in short term such as money market funds, they should have more of money market instruments such as treasury bills, commercial paper and investment in Fixed deposits and less of equity. Greater investment in equity should be considered when investing in funds where investors expect to make reasonable returns in the medium to long term.

Listed firms should be encouraged to issue corporate bonds and commercial paper. This can be achieved through proper guidelines and appropriate promotions by CMA. They are high yielding financial instruments which fund managers should give specific attention to.

Asset allocation has to be assessed alongside other investment aspects such as timing, manager experience and the prevailing economic conditions of operation when making an investment decision.

\subsection{Limitations of the study}

Collecting the secondary data from Unit Trusts Schemes in Kenya was herculean. The researcher had to approach the schemes individually to get the data where the financial statements were not available on their website. The organizations needed a lot of convincing that it was to be used exclusively for academic purposes to fill in the data collection form. The researcher ended up in the University of Nairobi Archives to get financial statements of the Unit Trust Schemes which were not willing to give the information. Therefore, the data collection process took longer than expected. Afterwards, data analysis and presentation of the results has been handled with a lot of confidentiality.

The study focused only on Unit Trust Schemes which represents part of the investment institutions we have in Kenya. Asset allocation is a critical investment decision which all investment institutions have to do it right for them to make reasonable returns and attract clients. The study was also limited to only Unit Trust Schemes in Kenya. A comparison of the findings between the local Unit Trust Schemes and the rest of the world would have given more insights and probably yield a more efficient way to tackle some of the common asset allocation mistakes committed.

The research was carried out for a period of over five-month period. Due to previously unforeseen circumstances, this proved to be a challenge to the researcher. Despite the time constraint, the researcher worked out an aggressive plan that saw it that all the challenges are addressed, and the quality of the research is held to extremely high standards. 
The study measured financial performance of the dependent variable using investment returns. Sharpe ratio was adopted to measure the returns. The measurement was adopted after careful assessment of on how Unit Trust Schemes work in Kenya and on which method is commonly adopted to measure fund returns. However, the researcher understands too well that other methods which are equally as good exist.

The researcher adopted a linear regression model to assess the association which existed between the independent and dependent variables. The model was later tested and found to adequately represent the relationship well. However, some of variables might not exhibit a linear relationship with the dependent variable.

\subsection{Suggestions for Further Studies}

This research was limited to the assessment of the effect of asset allocation in the financial performance of Unit Trust Schemes in Kenya. The discussion can be expanded to other investment organizations whereby asset allocation is a significant decision that its leadership grapple with on a day to day basis. Comparison of the local funds' performance with global leaders in the industry will also be beneficial to theory, practice, and policy.

One of the assumptions which this research adopted and some variables like equity and fund age violated is existence of a linear relationship between the independent and dependent variables. Adoption of a better model fit for the variables will give further insights into the nature of association which exists between the variables.

Annualized returns were collected over a 5-year period for all the Unit Trust Scheme funds in Kenya. The researcher feels that a replica study can be conducted over a longer time period for more conclusive findings.

Adequate timelines to conduct out such a study is also required. Much time was taken up during the data collection process, analysis, and presentation. Without sufficient time, the researcher will find himself/herself in an awkward position which might compromise the quality of the research.

Practitioners, scholars, and regulators will greatly benefit from a replica study which adopts a different approach of getting to measure investment returns. Some of the shortcomings of the Shape ratio are mitigated by Sortino and Treynor's ratios. However, their selection and adoption should follow after good assessment and convincing logic - they should not be used for the sake of it.

\section{ACKNOWLEDGEMENTS.}

Many thanks to my supervisors, Mr. Ronald Chogii and Dr. Winnie Nyamute who continually guided me throughout my thesis. Much appreciation to my mum, Mrs. Mary Mokaya and sister, Ms. Charlotte Mokaya for their emotional and financial support throughout my research.

My colleagues at Turnkey Africa Limited and KOKO Networks, I am profoundly grateful for your support and criticisms.

Last but not least, thanks to all the personnel in the various Unit Trust Schemes who gladly filled my data collection form and for those who pointed me to the right 
direction where I could get data for my research

\section{References}

[1] Blake, D., Lehmann, B.N., and Timmermann, A. (1998). Asset allocation dynamics and pension fund performance. The Journal of Business, 1999, vol. 72 , issue.

[2] Dziwok, E. (2014). Asset Allocation Strategy in Investment Portfolio Construction - A Comparative Analysis. Journal of Economics \& Management.

[3] Lintner, J. (1965). The valuation of risk assets and the selection of risky investments in stock portfolios and capital budgets. Review of Economics and Statistics. 47 (1): 13-37.

[4] Markowitz, H. (1952). Portfolio Selection. The Journal of Finance, Vol. 7, No. 1, pp. 77-91.

[5] Markowitz, H. M. (1991). Foundations of portfolio theory. The Journal of Finance, 46 (2), 469477.

[6] Sang, F. K. (2017). The effect of asset allocation on the financial performance of Unit Trust Schemes in Kenya. Unpublished Master of Business Administration Thesis, University of Nairobi.

[7] Santacruz, L. (2011). Strategic Asset Allocation and Portfolio Performance. Journal of Management Research, Vol. 1, No. 2, 2011. Available at SSRN: https://ssrn.com/abstract=2163899

[8] Sharpe, W. F. (1964). Capital Asset Prices: A theory of market equilibrium under conditions of risk. Journal of Finance. Vol.19 (3):425-442.

[9] Sharpe, W. F. (1966). Mutual Fund Performance. Journal of Business, 39(1), pp. 119-138.

[10] Sutcliffe, B. (2004). World Inequality and Globalization. Oxford Review of Economic Policy, Vol. 20, No.

[11] Treynor, J. L. (1965). How to rate the performance of mutual funds. Harvard Business Review. Vol.43:63-75.

[12] Velusamy, R., and Selvaveerakumar, B. (2014). A study on factors influencing investment in mutual fund among the investors with reference to Madurai district. Research gate publications 